\title{
Effect of gill removal and gutting on the quality of Tilapia (Oreochromis niloticus) under different storage condition
}

\author{
W. $\operatorname{Uddin}^{1}$, M. G. Rasul ${ }^{1,2 *}$, M. M. Hossain ${ }^{1}$, B. C. Majumdar' ${ }^{2}$, M. S. Rahman ${ }^{1}$, M. A. J. Bapary ${ }^{1}$ \\ ${ }^{1}$ Department of Fisheries Technology and Quality Control, Sylhet Agricultural University, Sylhet, Bangladesh. \\ ${ }^{2}$ Department of Fisheries Technology, Bangabandhu Sheikh Mujibur Rahman Agricultural University, Gazipur, Bangladesh.
}

\section{ARTICLE INFO}

Article history:

Received on: 30/05/2017

Accepted on: 05/07/2017

Available online: 30/10/2017

Key words:

Oreochromis niloticus,

Organoleptic, Nutritional quality,

Microbial load, Storage.

\begin{abstract}
The study was conducted to investigate the effect of gill removal and gutting on the quality of Tilapia fish (Oreochromis niloticus) during different storage period using organoleptic, biochemical and microbiological aspects. There were two groups of samples of which one was intact and other was gill and gut removed. On the basis of sensory evaluation, processed fish showed higher shelf life than intact fish in every storage condition. For intact and processed fish, proximate analysis showed that moisture content raised slightly; protein and lipid content reduced gradually and ash had little change at ambient temperature, ice and frozen storage condition. At every storage condition, $\mathrm{pH}$ of both samples was rapidly decreased, then again it increased gradually. Microbial load of the intact sample increased from $3.11 \times 10^{5} \mathrm{CFU} / \mathrm{g}$ to $8.5 \times 10^{6} \mathrm{CFU} / \mathrm{g}$ in ice stored sample whereas microbial load of processed sample was $2.7 \times 10^{4} \mathrm{CFU} / \mathrm{g}$ to $5.2 \times 10^{5} \mathrm{CFU} / \mathrm{g}$ at $15^{\text {th }}$ day of observation. On the other hand, microbial load of the intact sample at frozen storage increased from $3.11 \times 10^{5} \mathrm{CFU} / \mathrm{g}$ to $2.8 \times 10^{8} \mathrm{CFU} / \mathrm{g}$ but the microbial load of the processed sample increased at a level of $2.7 \times 10^{4} \mathrm{CFU} / \mathrm{g}$ to $1.9 \times 10^{7} \mathrm{CFU} / \mathrm{g}$. Finally it is revealed that the removal of gill and gut decrease the rate of spoilage in fish which resulted in an extension of shelf life with higher nutritional value.
\end{abstract}

\section{INTRODUCTION}

From the time immemorial, fish is an ideal food item in Bangladesh for many reasons. Currently, the fisheries sector in Bangladesh already provides $60 \%$ of the total national demand for animal protein (15\% of total protein intake) [1,2]. More than one billion people like fish and fishery products as the most important animal-source food in diets [3]. A daily intake of 250 mg EPA+DHA per adult gives optimal protection against CHD [4]. But this huge amount of captured and cultured fishes is going to be lost by spoilage many times due to lack of proper handling, processing and management during storage and transportation. This spoilage of food products can be due to chemical, enzymatic or microbial activities. Chemical deterioration and microbial spoilage are responsible for loss of $25 \%$ of gross primary agricultural and fishery products every year [5] and 30\% of landed fish [6] are lost through microbial activity alone.

\section{* Corresponding Author}

Md. Golam Rasul, Department of Fisheries Technology, Bangabandhu Sheikh Mujibur Rahman Agricultural University, Gazipur, Bangladesh. Email: rasul.gsau@gmail.com
Fresh fish spoilage can be very rapid after it is caught. The spoilage process (Rigor mortis) wills start within $12 \mathrm{hr}$ of their catch in the high ambient temperatures of the tropics [7]. During fish spoilage, there is a breakdown of various components which are responsible for the changes in odor, flavor and texture of the fish meat. To prevent the spoilage of fish, low temperature storage and chemical techniques for controlling water activity, enzymatic, oxidative and microbial spoilage are the most common in the industry today $[7,8]$. But any technique for preservation cannot ensure the total prevention of microbial and enzymatic activity when the intestine and gill are present in the whole fish. As the main source of microbes in fish; the gill and gut are removed the microbial load of fish will be decreased which will extend the shelf life of fish. However, it simply impedes the physical and biochemical reactions which are responsible for spoilage of food. Low storage temperature has significant influence on nutritional quality. The change of proteins results in dull and opaque texture and the tissue becomes soft and spongy which severely affects the quality of fish product [9]. The objectives of this study were to determine the effect of gill removal and gutting on the quality of Oreochromis niloticus with the extension of shelf life during storage and recommend a suitable technique to prevent quality loss for using in commercial purpose. 


\section{MATERIALS AND METHODS}

\subsection{Collection of samples}

The edible freshwater fish (Oreochromis niloticus) with the length of 7-8 cm weighing 180-200 g were collected from the fish culture pond of a local fishery owner of Sylhet. The fishes were immediately transported to the Fish Processing and Quality Control Laboratory, Sylhet Agricultural University and were kept at ambient temperature $\left(25-28^{\circ} \mathrm{C}\right)$ in trays. A portion of sample fish was also carried to the Microbiological Laboratory of Faculty of Fisheries, Sylhet Agricultural University. On arrival to the laboratory, the fish were sacrificed by shock treatment. The samples were firstly divided into two groups which was again divided into 3 sub-groups and then they were further stored at different temperatures. First group was kept at room temperature samples. Second group was put in an insulated container and mixed with ice, ratio $1: 1$, layer of ice and layer of fish. The third group was packed with plastic bag and stored at frozen condition $\left(-8^{\circ} \mathrm{C}\right)$. However, the two major groups of the samples were-

Sample A: Controlled or intact fish sample (Only washed with distilled water)

Sample B: Fish sample which was gutted, gill removed and washed with chilled water

\subsection{Organoleptic Assessments of Experimental Fish}

Organoleptic characteristics such as color, odor and texture of the fishes (Oreochromis niloticus) will be examined by organoleptic test/sensory test. Organoleptic characteristics were done by panel members based on Howgate [10].

\subsection{Proximate composition analysis}

The moisture, protein, crude lipid and ash content in Oreochromis niloticus were analyzed with the help of Hot air oven, Kjeldhal apparatus, Soxhlet apparatus and Muffle furnace, respectively following the method described by AOAC method [11].

\subsection{Determination of $\mathrm{pH}$ value}

For the determination of $\mathrm{pH}, 5 \mathrm{~g}$ of sample will be weighed using electronic balance and taken in a beaker. Then the sample will be homogenized using tissue homogenizer with 10 volumes of distilled water and finally the $\mathrm{pH}$ will be measured using digital $\mathrm{pH}$ meter (HANNA pH 211 Microprocessor pH Meter).

\subsection{Microbiological Analysis}

The microbiological characteristics such as Total plate count (TPC) of fish (Oreochromis niloticus) samples were enumerated by using plate count agar by APHA method [12].

\subsection{Data Analysis}

Analysis was performed in triplicates and the results expressed as mean \pm standard deviation using Statistical Package for the Social Sciences (SPSS) 16.0 for windows (SPSS, SAS Institute Inc. Cary, USA).

\section{RESULTS AND DISCUSSION}

\subsection{Organoleptic quality evaluation of the Samples under various storage conditions}

Initially the fish shows excellent grade of quality while judged by the panel of expert. It has been observed that this quality deteriorate with the increase of storage time. The results of the organoleptic quality assessment of controlled and processed tilapia (Oreochromis niloticus) which were stored at ambient temperature, ice condition and frozen condition are presented in Table 1, Table 2 and Table 3. The grades were defined in terms of the total number of defects or demerit points based on Howgate [10]. In Table 1, it was found that sample A (intact fish) remained acceptable up to $8^{\text {th }}$ hours and $12^{\text {th }}$ hours for sample B (processed fish).

Though the physical appearance of both the sample was more or less similar but there was a clear difference in texture, odor and condition of eye between two types of sample. It was found that the shelf life of sample B was extended $4 \mathrm{hrs}$ more than that of the sample A. The acceptability of Oreochromis niloticus was about $9^{\text {th }}$ hrs at ambient temperature [13]. Our finding is agreed with Adoga [14].

During ice storage condition (Table 2), it was found that sample A remained acceptable up to $12^{\text {th }}$ days (Defect point 4.25) and sample $B$ was rejected after $21^{\text {th }}$ days (Defect point 4.6). It has been reported that both chemical analyses and visual appearance examination showed that the quality of rohu fish (Labeo rohita) was in acceptable condition up to $17^{\text {th }}$ days of ice storage [15]. The above study is more or less in agreement to Hossain [13] who observed that the results of organoleptic assessment and microbial assessment in Oreochromis niloticus were in acceptable condition for $15^{\text {th }}$ days in ice.

In case of Frozen storage (Table 3), the Defect Points of the sample A were 1, 1.52, 2.33, 3.14, 3.57, and 4.26 respectively at $0^{\text {th }}, 15^{\text {th }}, 30^{\text {th }}, 45^{\text {th }}, 60^{\text {th }}$ and $90^{\text {th }}$ days of observation period which fall into A, A, B, B, B and B grades, respectively. On the other hand, sample B showed the Defect Points of 1, 1.25, 2.01, $2.85,2.88$, and 3.42 respectively at $0^{\text {th }}, 15^{\text {th }}, 30^{\text {th }}, 45^{\text {th }}, 60^{\text {th }}$ and $90^{\text {th }}$ days of observation period which fall into A, A, B, B, B, B, B and B grades respectively. Akter [16] reported that Pangus $(P$. hypophthalmus) fillet quality during frozen storage remained acceptable for $120^{\text {th }}$ days whereas after $150^{\text {th }}$ days became inedible.

Due to the removal of gill and gut, the microbial activity and enzymatic activity of the processed sample was lessened which results in a good quality and extended shelf life of the sample. 
Table 1: Organoleptic quality of Tilapia (Oreochromis niloticus) samples that were kept under ambient temperature $\left(25-28^{\circ} \mathrm{C}\right)$.

\begin{tabular}{|c|c|c|c|c|c|}
\hline $\begin{array}{l}\text { Observation } \\
\text { Period (Hrs) }\end{array}$ & Sample & Organoleptic Qualities & $\begin{array}{l}\text { Defect } \\
\text { Points }\end{array}$ & Grade & $\begin{array}{l}\text { Overall } \\
\text { Qualities }\end{array}$ \\
\hline \multirow[t]{2}{*}{0} & A & Fresh, bright appearance, soft and firm texture with characteristics of natural fishy odor. & 1 & A & Excellent \\
\hline & B & & & & \\
\hline \multirow[t]{2}{*}{4} & A & $\begin{array}{l}\text { Slight dullness and loss of bloom, Slight cloudy of lens and sunken, moderately soft and } \\
\text { some loss of elasticity }\end{array}$ & 2.38 & B & Good \\
\hline & B & $\begin{array}{l}\text { Slight dullness and loss of bloom, soft and firm texture with characteristics of natural fishy } \\
\text { odor. }\end{array}$ & 1.57 & A & Excellent \\
\hline \multirow[t]{2}{*}{8} & A & $\begin{array}{l}\text { Dull appearance with blood and slime on surface, texture begin to show obvious signs of } \\
\text { spoilage }\end{array}$ & 4.17 & B & Acceptable \\
\hline & B & Considerable loss of flavor and odor; slimy surface and moderately soft texture; & 2.9 & B & Acceptable \\
\hline \multirow[t]{2}{*}{12} & A & The fish is putrid by all of the characteristics. & 5.0 & $\mathrm{C}$ & Rejected \\
\hline & B & Soft texture and slime on surface; moderate loss of flavor and odor. & 3.45 & B & Acceptable \\
\hline \multirow[t]{2}{*}{18} & A & Rejected & - & - & Rejected \\
\hline & B & The fish is putrid by all of the characteristics. & 5.0 & $\mathrm{C}$ & Rejected \\
\hline
\end{tabular}

Table 2: Sensory Evaluation of Tilapia (Oreochromis niloticus) at Different Days of Ice Storage $\left(0^{\circ} \mathrm{C}\right)$ in an Insulated Box

\begin{tabular}{|c|c|c|c|c|c|}
\hline $\begin{array}{l}\text { Observation } \\
\text { Period (days) }\end{array}$ & Sample & Organoleptic Qualities & $\begin{array}{l}\text { Defect } \\
\text { Points }\end{array}$ & Grade & $\begin{array}{l}\text { Overall } \\
\text { Qualities }\end{array}$ \\
\hline \multirow[t]{2}{*}{0} & A & Fresh, bright appearance, soft and firm texture with characteristics of natural fishy odor. & 1 & A & Excellent \\
\hline & B & & & & \\
\hline \multirow[t]{2}{*}{3} & A & A decrease in the brightness; slightly softer texture, natural fishy odor. & 1.87 & A & Excellent \\
\hline & B & $\begin{array}{l}\text { A decrease in the brightness; firm texture, natural fishy odor, bulging with protruding lens, } \\
\text { transparent eye cap }\end{array}$ & 1.25 & A & Excellent \\
\hline \multirow[t]{2}{*}{6} & A & Loss in brightness; slight loss of the natural odor and loss of bloom & 2.30 & B & Good \\
\hline & B & Some loss in brightness; slight loss of the natural odor and slime & 1.57 & A & Excellent \\
\hline \multirow[t]{2}{*}{9} & A & Loss of slime in surface and soft texture; faint odor, sunken, cloudy eye & 3.13 & B & Acceptable \\
\hline & B & Slight slime in surface and slight soft texture; slight loss of flavor and odor. & 2.00 & & Good \\
\hline \multirow[t]{2}{*}{12} & A & $\begin{array}{l}\text { Dull appearance with blood and slime on surface, texture begin to show obvious signs of } \\
\text { spoilage }\end{array}$ & 4.25 & B & Acceptable \\
\hline & B & Considerable loss of flavor and odor; slimy surface and moderately soft texture; & 2.9 & B & Acceptable \\
\hline \multirow[t]{2}{*}{15} & A & The fish is putrid by all of the characteristics. & 5.0 & $\mathrm{C}$ & Rejected \\
\hline & B & Soft texture and slime on surface; moderate loss of flavor and odor. & 3.22 & B & Acceptable \\
\hline \multirow[t]{2}{*}{18} & A & Rejected & - & - & Rejected \\
\hline & B & Soft texture; bloody appearance; loss of flavor and odor. & 3.97 & B & Acceptable \\
\hline \multirow[t]{2}{*}{21} & A & Rejected & - & - & Rejected \\
\hline & B & $\begin{array}{l}\text { Fish has dull appearance with blood and slime on surface not uniformly distributed; texture } \\
\text { begin to show obvious signs of spoilage. }\end{array}$ & 4.6 & B & $\begin{array}{l}\text { In the limit } \\
\text { Acceptance }\end{array}$ \\
\hline \multirow[t]{2}{*}{25} & A & Rejected & - & - & Rejected \\
\hline & B & The fish is putrid by all of the characteristics. & 5.0 & $\mathrm{C}$ & Rejected \\
\hline
\end{tabular}

Table 3: Sensory Evaluation of Tilapia (Oreochromis niloticus) at Different Days of Frozen Storage $\left(-8^{\circ} \mathrm{C}\right)$

\begin{tabular}{|c|c|c|c|c|c|}
\hline $\begin{array}{l}\text { Observation } \\
\text { Period (days) }\end{array}$ & Sample & Organoleptic Qualities & $\begin{array}{l}\text { Defect } \\
\text { Points }\end{array}$ & Grade & $\begin{array}{l}\text { Overall } \\
\text { Qualities } \\
\end{array}$ \\
\hline 0 & $\begin{array}{ll}\mathrm{A} \\
\mathrm{B}\end{array}$ & $\begin{array}{l}\text { Natural fishy odor; bright red gill; full bloom, bright and Shining; transparent eye; firm and } \\
\text { elastic flesh. }\end{array}$ & 1 & A & Excellent \\
\hline \multirow[t]{2}{*}{15} & A & Moderate faint odor, bright red gill; , slight dullness, after thawing muscle become slight soft & 1.52 & B & Excellent \\
\hline & B & Natural odor, pinkish red, loss of bloom, after thawing muscle become slight soft & 1.25 & B & Excellent \\
\hline \multirow[t]{2}{*}{30} & A & $\begin{array}{l}\text { Faint odor, pinkish red gill, dull appearance, after thawing muscle become slight soft, belly } \\
\text { burst }\end{array}$ & 2.33 & B & Acceptable \\
\hline & B & Faint odor, loss of bloom, after thawing muscle become slight soft & 2.01 & B & Acceptable \\
\hline \multirow[t]{2}{*}{45} & A & $\begin{array}{l}\text { Moderate sour odor; pink gill; slightly dullness and loss of bloom; slightly cloudy lens and } \\
\text { sunken eye; some softening of flesh. }\end{array}$ & 3.14 & B & Acceptable \\
\hline & B & Faint odor, pinkish red, loss of bloom, after thawing muscle become slight soft & 2.85 & B & Acceptable \\
\hline \multirow[t]{2}{*}{60} & A & $\begin{array}{l}\text { Faint odor, slight grey color, dull appearance, after thawing muscle become slight soft, belly } \\
\text { burst }\end{array}$ & 3.57 & B & Acceptable \\
\hline & B & Faint odor, loss of bloom, after thawing muscle become slight soft & 2.88 & B & Acceptable \\
\hline \multirow[t]{2}{*}{90} & $\mathrm{~A}$ & $\begin{array}{l}\text { Faint odor, slight grey color, dull appearance, after thawing muscle become slight soft, belly } \\
\text { burst }\end{array}$ & 4.26 & B & Acceptable \\
\hline & B & $\begin{array}{l}\text { Sour odor; brown gill; loss of bloom; cloudy lens and sunken eye cap; some softening of } \\
\text { flesh }\end{array}$ & 3.42 & B & Acceptable \\
\hline
\end{tabular}


Table 4: Changes in Proximate Composition of Tilapia (Oreochromis niloticus) at Different Keeping Time at Various Storage Conditions.

\begin{tabular}{|c|c|c|c|c|c|c|c|c|c|}
\hline \multirow{3}{*}{ 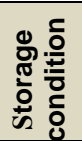 } & \multirow{3}{*}{$\begin{array}{c}\text { Time of } \\
\text { observation }\end{array}$} & \multicolumn{8}{|c|}{$\begin{array}{c}\text { Proximate composition } \\
\end{array}$} \\
\hline & & \multicolumn{2}{|c|}{ Moisture (\%) } & \multicolumn{2}{|c|}{ Protein $(\%)$} & \multicolumn{2}{|c|}{ Lipid (\%) } & \multicolumn{2}{|c|}{$\operatorname{Ash}(\%)$} \\
\hline & & A & B & $\mathbf{A}$ & B & $\mathbf{A}$ & $\mathbf{B}$ & $\mathbf{A}$ & B \\
\hline \multirow{5}{*}{ 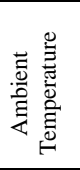 } & $0 \mathrm{hr}$ & $76.92 \pm 0.09$ & $76.92 \pm 0.10$ & $16.91 \pm 0.28$ & $16.91 \pm 0.43$ & $3.21 \pm 0.17$ & $3.21 \pm 0.28$ & $2.11 \pm 0.16$ & $2.11 \pm 0.47$ \\
\hline & $4 \mathrm{hrs}$ & $76.86 \pm 0.19$ & $76.66 \pm 0.29$ & $15.34 \pm 0.17$ & $15.75 \pm 0.18$ & $3.15 \pm 0.13$ & $3.23 \pm 0.47$ & $2.34 \pm 0.02$ & $2.38 \pm 0.17$ \\
\hline & $8 \mathrm{hrs}$ & $76.47 \pm 0.13$ & $76.02 \pm 0.31$ & $15.23 \pm 0.43$ & $15.61 \pm 0.17$ & $3.19 \pm 0.08$ & $3.20 \pm 0.08$ & $2.38 \pm 0.13$ & $2.39 \pm 0.03$ \\
\hline & $12 \mathrm{hrs}$ & $76.13 \pm 0.27$ & $75.89 \pm 0.23$ & $15.16 \pm 0.55$ & $15.56 \pm 0.26$ & $3.25 \pm 0.41$ & $3.17 \pm 0.15$ & $2.41 \pm 0.07$ & $2.39 \pm 0.13$ \\
\hline & $18 \mathrm{hrs}$ & Rejected & $74.32 \pm 0.05$ & Rejected & $15.04 \pm 0.11$ & Rejected & $3.24 \pm 0.12$ & Rejected & $2.24 \pm 0.15$ \\
\hline \multirow{5}{*}{ 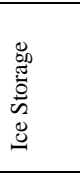 } & 0 day & $76.92 \pm 0.07$ & $76.92 \pm 0.56$ & $16.91 \pm 0.08$ & $16.91 \pm 0.16$ & $3.21 \pm 0.47$ & $3.21 \pm 0.34$ & $2.11 \pm 0.46$ & $2.11 \pm 0.34$ \\
\hline & 7 days & $78.97 \pm 0.24$ & $78.65 \pm 0.08$ & $15.24 \pm 0.13$ & $15.88 \pm 0.34$ & $2.77 \pm 0.28$ & $2.45 \pm 0.07$ & $1.43 \pm 0.03$ & $1.69 \pm 0.18$ \\
\hline & 15 days & $80.07 \pm 0.41$ & $79.57 \pm 0.34$ & $13.43 \pm 0.47$ & $15.09 \pm 0.28$ & $1.97 \pm 0.51$ & $2.05 \pm 0.13$ & $1.23 \pm 0.47$ & $1.57 \pm 0.16$ \\
\hline & 21 days & $82.14 \pm 0.52$ & $80.04 \pm 0.19$ & $12.06 \pm 0.08$ & $14.89 \pm 0.51$ & $1.34 \pm 0.43$ & $2.02 \pm 0.09$ & $1.11 \pm 0.15$ & $1.54 \pm 0.23$ \\
\hline & 25 days & Rejected & $80.32 \pm 0.25$ & Rejected & $14.04 \pm 0.13$ & Rejected & $1.97 \pm 0.16$ & Rejected & $1.53 \pm 0.11$ \\
\hline \multirow{5}{*}{ 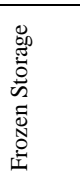 } & 0 day & $76.92 \pm 0.39$ & $76.92 \pm 0.32$ & $16.91 \pm 0.48$ & $16.91 \pm 0.54$ & $3.21 \pm 0.45$ & $3.21 \pm 0.33$ & $2.11 \pm 0.12$ & $2.11 \pm 0.29$ \\
\hline & 15 days & $73.42 \pm 0.45$ & $73.04 \pm 0.44$ & $15.22 \pm 0.08$ & $15.75 \pm 0.20$ & $3.09 \pm 0.34$ & $3.13 \pm 0.47$ & $2.34 \pm 0.39$ & $2.38 \pm 0.19$ \\
\hline & 30 days & $72.13 \pm 0.24$ & $71.87 \pm 0.20$ & $14.16 \pm 0.33$ & $15.16 \pm 0.39$ & $3.25 \pm 0.57$ & $3.26 \pm 0.32$ & $2.47 \pm 0.17$ & $2.52 \pm 0.34$ \\
\hline & 60 days & $70.34 \pm 0.22$ & $69.54 \pm 0.43$ & $13.70 \pm 0.47$ & $14.69 \pm 0.24$ & $3.36 \pm 0.18$ & $3.38 \pm 0.09$ & $2.60 \pm 0.24$ & $2.71 \pm 0.47$ \\
\hline & 90 days & $68.11 \pm 0.35$ & $67.11 \pm 0.31$ & $13.03 \pm 0.15$ & $14.20 \pm 0.33$ & $3.27 \pm 0.29$ & $3.40 \pm 0.17$ & $2.64 \pm 0.43$ & $2.79 \pm 0.15$ \\
\hline
\end{tabular}

*Values are mean \pm Standard deviation (SD)

\subsection{Changes in Nutritional Parameters of both Samples under Various Storage Conditions}

Biochemical composition of fresh Tilapia fish (Oreochromis niloticus) was determined under laboratory condition immediately after collection of sample. The trend of proximate composition was moisture $(76.92 \%)>$ protein $(16.91 \%)$ $>$ lipid $(3.21 \%)>$ ash $(2.11 \%)$. Fish muscle $\mathrm{pH}$ was near neutral 7.10. According to Nowsad [17], total proximate composition (moisture, protein, lipid and ash) in fish tissue accounts for about 96-98\% where sum of lipid and moisture range from 78 to $85 \%$.

\subsubsection{Moisture content}

The initial moisture content of fresh Tilapia (Oreochromis niloticus) was $76.92 \%$. However the moisture content in the sample A stored at ambient temperature at $12^{\text {th }} \mathrm{hr}$ was found 76.13 and $75.89 \%$ in the sample B (Table 4). The variation in the moisture content in intact fish and processed fish clearly showed that processed fish had much higher moisture loss during this period at ambient temperature. Moisture content of intact fish and processed fish stored at ice condition increased with the increase of storage period (Table 4). At Frozen Storage condition, moisture content showed a gradual decrease at with the increase of storage period (Table 4). The fish absorbs water from the melted ice which results in an increase in the moisture content of the samples. In a study with three species of marine fishes, Kamal [18] showed an increase in moisture content during ice storage. Similar result was found by Reza [19] with three species of marine fishes.

\subsubsection{Protein content}

The initial protein content of fresh Tilapia (Oreochromis niloticus) was $16.91 \%$ which decreased at a level of $15.16 \%$ for sample A and $15.56 \%$ for sample B at Ambient Temperature during $12^{\text {th }}$ hour of preservation (Table 4). Changes in protein content of the samples were observed a gradual decrease in all the storage conditions. At ice storage condition, this study showed that the initial protein content of both the samples were $16.91 \%$ which decreased at $13.43 \%$ for intact fish and $15.09 \%$ for processed fish after 15 days of observation. Reza [19] observed the changes in that the protein content of marine fishes; Silver jewfish, Bombay duck, Big-eye tuna, Chinese pomfret and Ribbon fishes during ice storage condition. They found that the protein content decreased gradually during ice storage periods of $0-13$ days which ranged from $16.30 \%-12.10 \%, 8.96 \%-7.20 \%, 19.90 \%-17.82 \%, 17.20 \%$ $-16.91 \%$ and $11.70 \%-10.12 \%$, respectively for the fish samples. At Frozen Storage condition, protein content was recorded at a gradual decrease with the increase of storage period. The denaturation of protein, drip loss may be the cause of protein loss during different storage condition.

\subsubsection{Lipid Content}

During ice storage the lipid content was observed to be decreased with the increase of storage period where as the lipid content of frozen storage sample showed a gradual increase (Table 4). At ambient temperature the lipid content was found 3.21 $3.25 \%$ at intact fish and $3.21-3.17 \%$ at processed fish from $0-12^{\text {th }}$ hrs of observation period. Reza [19] observed the lipid content of marine fishes Silver jewfish, Bombay duck, Big-eye tuna, Chinese pomfret and Ribbon fishes during ice storage condition. In their result they showed that the protein content decreased gradually during ice storage periods of $0-13^{\text {th }}$ days and it ranged from $6.0 \%$ $5.86 \%, 1.10 \%-0.8 \%, 6.70 \%-4.60 \%, 6.0 \%-5.66 \%$ and $6.0 \%-$ $5.50 \%$, respectively. The trend of decreasing lipid is very much similar to the obtained values of the present study.

\subsubsection{Ash Content}

In the present study, the ash content of ambient temperature stored sample increased with the increase of time. The ice content was increased from 2.11-2.41\% at intact fish and 2.11$2.39 \%$ at processed fish at $0-12^{\text {th }}$ hrs of storage (Table 4).During ice storage condition the Ash content of Sample A and B decreased in a gradual manner. At frozen storage condition, ash 
content of both intact and processed fish was gradually increased with the increase of storage period. Similar finding was also reported by Arannilewa [20]. Therefore, it can be concluded that proximate composition of the fish is variable and dependent upon the species, size, sex and age of the fish, its geographical distribution and season of the year. Our result is agreed with Laila [21].

\subsection{Changes in $\mathbf{p H}$ under various storage conditions}

The initial pH content of fresh Tilapia (Oreochromis niloticus) was 7.10. However at every storage conditions, $\mathrm{pH}$ of both samples was rapidly reduced up to middle part of the storage time, then again it increased gradually (Table 5). It has been investigated that the initial $\mathrm{pH}$ of Pangasius sutchi was around 7.0 which gradually reduced to 5.98 during $14^{\text {th }}$ days of ice storage period and then increased [13]. Reza [19] also observed that, for different fish species such as Silver jewfish, Bombay duck, Bigeye tuna, Chinese pomfret and ribbon fish the $\mathrm{pH}$ gradually increased with the lapse of storage period, and at the end of 13 days of storage the $\mathrm{pH}$ increased up to 7.98 and it ranged within 7.2-7.98.Our results were very much similar with the result of Reza [22]. The initial low $\mathrm{pH}$ was because of formation of lactic acid during anaerobic glycolysis in fish muscle might be after the death. It is also remarkable that the rate of decreasing $\mathrm{pH}$ value of sample A is greater than that of sample B.

\subsection{Changes in Microbial Load under various storage conditions}

Microbial load during fresh condition of (Oreochromis niloticus) was found $3.11 \times 10^{5} \mathrm{CFU} / \mathrm{g}$ and $2.7 \times 10^{4} \mathrm{CFU} / \mathrm{g}$ for intact (i.e. sample A) and processed sample (i.e. sample B); respectively (Table 5). These total plate count was observed increasing with the increase of storage period at ice condition. The total plate count at $7^{\text {th }}$ day of observation was $2.2 \times 10^{6} \mathrm{CFU} / \mathrm{g}$ and $3.0 \times 10^{5} \mathrm{CFU} / \mathrm{g}$ for sample A and B respectively where both of the sample in acceptable condition. At $21^{\text {th }}$ day the microbial load of sample A was found $9.1 \times 10^{7} \mathrm{CFU} / \mathrm{g}$ which acceded the limit of standard and was rejected whereas the sample B showed a microbial load of $2.6 \times 10^{6} \mathrm{CFU} / \mathrm{g}$. The final microbial load of the sample B at $25^{\text {th }}$ day at ice storage condition was found $9.5 \times 10^{7}$ $\mathrm{CFU} / \mathrm{g}$. At frozen storage condition microbial load of the samples was observed in a gradual increasing manner with the increase of storage time (Table 5). It is noticeable that the increasing rate of microbial load in case of sample B is lower than that of sample A at frozen storage condition.

Arannilewa [20] found that the total coliform count range was between $3.0 \times 10^{3}$ to $7.5 \times 10^{6}$ which increases with duration of frozen storage of Tilapia (Sarotherodun galiaenus). The results of microbiological analysis in this study are more or less alike to Adoga [14]. All the samples stored at different temperature showed a gradual decrease in the quality of fish where the rate of spoilage of fish were highest in case of room temperature. The rate of spoilage in case of ice stored sample slower than that of ambient temperature kept sample and the rate was slowest in case of frozen storage sample. It may be due to the less microbial activity in icing and frozen condition and also the less enzymatic activity in fish. Again, the rate of spoilage in intact sample was found higher than that of the processed i.e. gutted and gill removed sample.

\section{CONCLUSION}

The result from the present study indicates that the removal of gill and intestine has a great impact on the quality of fish preserved under various storage conditions. The shelf life of the fish can be extended by removing gill and intestine with a good quality. This technology can also be implemented for commercial purpose at different stages of handling, preservation and transportation. Simple gill removal and gutting can enhance shelf life of fish not only at low temperature but also at room temperature. Fish processing industry and fish waste based industry can be developed on the basis of this technology.

Table 5: Changes in $\mathrm{pH}$ and Microbial Load of Tilapia (Oreochromis niloticus) at Different Keeping Time at Various storage conditions.

\begin{tabular}{|c|c|c|c|c|c|}
\hline \multirow{2}{*}{ Storage condition } & \multirow{2}{*}{ Observation Period } & \multicolumn{2}{|c|}{ pH } & \multicolumn{2}{|c|}{ Total Plate Count (CFU/g) } \\
\hline & & Treatment - A & Treatment - B & Treatment - A & Treatment - B \\
\hline \multirow{5}{*}{$\begin{array}{c}\text { Ambient } \\
\text { temperature }\end{array}$} & $0 \mathrm{hr}$ & $7.10 \pm 0.08$ & $7.10 \pm 0.03$ & - & - \\
\hline & $4 \mathrm{hrs}$ & $6.81 \pm 0.21$ & $7.01 \pm 0.42$ & - & - \\
\hline & $8 \mathrm{hrs}$ & $7.45 \pm 0.06$ & $6.96 \pm 0.29$ & - & - \\
\hline & $12 \mathrm{hrs}$ & $8.32 \pm 0.47$ & $7.99 \pm 0.54$ & - & - \\
\hline & $18 \mathrm{hrs}$ & Rejected & $8.22 \pm 0.17$ & - & - \\
\hline \multirow{5}{*}{ Ice storage } & 0 day & $7.10 \pm 0.16$ & $7.10 \pm 0.11$ & $3.11 \times 10^{5}$ & $2.7 \times 10^{4}$ \\
\hline & 7 days & $6.99 \pm 0.24$ & $7.02 \pm 0.32$ & $2.2 \times 10^{6}$ & $3.0 \times 10^{5}$ \\
\hline & 15 days & $6.67 \pm 0.19$ & $6.99 \pm 0.34$ & $8.5 \times 10^{6}$ & $5.2 \times 10^{5}$ \\
\hline & 21 days & $7.8 \pm 0.28$ & $7.4 \pm 0.21$ & $9.1 \times 10^{7}$ & $2.6 \times 10^{6}$ \\
\hline & 25 days & Rejected & $8.23 \pm 0.27$ & Rejected & $9.5 \times 10^{7}$ \\
\hline \multirow{5}{*}{ Frozen storage } & 0 days & $7.10 \pm 0.05$ & $7.10 \pm 0.30$ & $3.11 \times 10^{5}$ & $2.7 \times 10^{4}$ \\
\hline & 15 days & $7.05 \pm 0.32$ & $7.02 \pm 0.13$ & $9.3 \times 10^{5}$ & $2.6 \times 10^{5}$ \\
\hline & 30 days & $6.93 \pm 0.46$ & $6.98 \pm 0.36$ & $7.9 \times 10^{6}$ & $8.2 \times 10^{5}$ \\
\hline & 60 days & $7.98 \pm 0.28$ & $8.01 \pm 0.19$ & $9.4 \times 10^{7}$ & $2.5 \times 10^{6}$ \\
\hline & 90 days & $8.25 \pm 0.13$ & $8.39 \pm 0.21$ & $2.8 \times 10^{8}$ & $1.9 \times 10^{7}$ \\
\hline
\end{tabular}

*Values are mean \pm Standard deviation $(\mathrm{SD})$ 
Financial support and sponsorship: Nil.

Conflict of Interests: There are no conflicts of interest.

\section{REFERENCES}

1. Belton B, Karim M, Thilsted S, Jahan KME, Collis W, Phillips M. Review of aquaculture and fish consumption in Bangladesh. Studies and Reviews 2011-53. The World Fish Center. 2011.

2. DOF. National Fisheries Week Souvenir. Department of Fisheries, Matshaya Bhaban, Dhaka. 2014.

3. Tacon AGJ, Metian M. Fishing for aquaculture: non-food use of small pelagic forage fish-a global perspective. Reviews in Fisheries Science. 2009; 17 (3): 305-317.

4. Mozaffarian D, Rimm EB. Fish intake, contaminants, and human health: evaluating the risks and the benefits. Journal of the American Medical Informatics Association. 2006; 296: 1885-1899.

5. Baird-Parker TC. The Production of Microbiologically Safe and Stable Foods. In: The Baliga, B.R, M.N. and Lahiry, N.L. (Central Food Technology Research Inistitute, Mysore - 2. India) 1962. Extraction of sarcoplasmic fraction of fish muscle with salt solution of different ionic strength and $\mathrm{pH}$. Food Technology, Champaign. 2000; 16 (2): 86-88.

6. Amos B. Analysis of quality deterioration at critical steps/points in fish handling in Uganda and Iceland and suggestions for improvement. United Nations University, Uganda. 2007.

7. Berkel BM, Boogaard BV, Heijnen C. Preservation of Fish and Meat. Agromisa Foundation, ISBN: 90-72746-01-9, Wageningen, The Netherlands. 2004, p. 78-80.

8. Akinola OA, Akinyemi AA, Bolaji BO. Evaluation of traditional and solar drying systems towards enhancing fish storage and preservation in Nigeria Abeokuta local government as a case study. Journal of Fisheries International. 2006; 1: 44-49.

9. Graham J. Cold Storage. In: Fish Handling and Processing, Aitken, A., I.M. Mackie, J.H. Merritt and M.L. Windsor (Eds.)., 2nd Ed., Tony Research Station, Edinburgh, UK. 1982, p. 2-78.

10. Howgate P, Johnston A, Whittle KJ. Multilingual guide to EC freshness grades for fishery products, Aberdeen, Scotland, UK: Torry Research Station. 1992.

11. AOAC, Association of Official Analytical Chemists. Official methods of analysis. Virginia: AOAC International. 1995.

12. APHA. Compendium of methods for the microbiological Examination of foods, p. 1264, 3rd Edition, C. Vander dent, and splittstoesser, D, (Eds), APHA, Washington DC. 1992.

13. Hossain MI, Islam MS, Shikha FH, Kamal M, Islam MN. Physicochemical changes in Thai pangus (Pangasius sutchi) muscle during ice-storage in an insulated box. Pakistan Journal of Biological Science. 2005; 8 (6): 798-804.
14. Adoga IJ, Egila J, Omojowo FS. Studies on the post-mortem changes in African Catfish (Clarias angullaris) during ice -storage. New York Science Journal. 2010b; 3 (6): 96-101.

15. Sravani K, Dhanapal K, Balasubramanian A, Reddy GVS. Biochemical changes and visual appearance of Indian Major Carp, Labeo rohita during ice storage. Asian Journal of Microbiology, Biotechnology and Environmental Sciences. 2013; 15 (1): 169-175.

16. Akter M, Islam MJ, Mian S, Shikha FH, Rahman MH, Kamal M. Changes in fillet quality of Pangus Catfish (Pangasianodon hypohthalmus) during frozen storage. World Journal of Fish and Marine Sciences. 2014; 6 (2): 146-155.

17. Nowsad AKMA. Participatory Training of Trainers: A New Approach Applied in Fish Processing. 1st Ed. Bangladesh Fisheries Research Forum, Mymensingh, Bangladesh. 2007.

18. Kamal M, Reza MS, Islam MN, Azimuddin KM. Influence of ice storage raw materials for the production of high quality dried products. Journal of Biological Science. 2006; 6 (1): 130-134.

19. Reza MS, Bapary MAJ, Islam MN, Ahasan TC, Kamal M. Shelf life of several marine fish species during ice storage. Journal of Food Science and Technology. 2009; 44: 1485-1494.

20. Arannilewa ST, Salawu SO, Sorungbe AA, Ola-Salawu BB. Effect of frozen period on the chemical, microbiological and sensory quality of frozen tilapia fish (Sarotherodun galiaenus). African Journal of Biotechnology. 2005; 4 (8): 852-855.

21. Laila DL, Zzaman W. Tajul AY. Effects of chilled- frozen storage on the physic-chemical, microbial and sensory quality of farmed Bighead carp (Hypophthalmichthys nobilis). Journal of Fisheries and Aquatic Science. 2013; 8 (6): 686-696.

22. Reza MS, Bapary MAJ, Islam MN, Ahasan TC, Kamal M. Optimization of marine fish drying using solar tunnel dryer. Journal of Food Processing and Preservation. 2008; 33: 47-59.

23. Adoga IJ, Joseph E, Samuel EF. Storage Life of Tilapia (Oreochromis niloticus) in ice and ambient temperature. Researcher. 2010a; 2 (5):39-44.

\section{How to cite this article:}

Uddin W, Rasul MG, Hossain MM, Majumdar BC, Rahman MS, Bapary MAJ. Effect of gill removal and gutting on the quality of Tilapia (Oreochromis niloticus) under different storage condition. J App Biol Biotech. 2017; 5 (05): 030-035. 